\title{
MUSIK KRITIS DALAM MEMBANGUN KESADARAN TERHADAP KONDISI SOSIAL POLITIK: STUDI KASUS MUSIKALISASI NYELENEH KARYA JASON RANTI BAGI GENERASI MUDA
}

\author{
Farah Amalia ${ }^{1}$, Haryadi $^{2}$ \\ ${ }^{1}$ Departemen Politik Fakultas Ilmu Sosial dan Ilmu Politik, Universitas Airlangga \\ farah.amalia-2017@fisip.unair.ac.id \\ ${ }^{2}$ Departemen Politik Fakultas Ilmu Sosial dan Ilmu Politik, Universitas Airlangga \\ haryadi@fisip.unair.ac.id
}

\begin{abstract}
Critical music has the ability to describe the socio-political reality that occur in the country. Musicians describe their concerns and ideas through lyrics found in critical music. Therefore, musicians take advantage of the function of music as mass communication. Through critical music, the delivery of socio-political phenomena can be intertwined in a more informal and relaxed manner, especially for the younger generation who are very close to the development of music, where Indonesia is in a demographic bonus phase. In this study, researcher attempted to explain the dynamics of critical music in Indonesia's political ecosystem and how it affects the critical awareness of the younger generation through the work of Jason Ranti. Jason Ranti describes his anxiety through the lyrics that are eccentric but rich in meaning, relaxed but not purposeless, and critical without being patronizing. Jason Ranti's critical music can build the interest of the younger generation to be more critical of the ongoing socio-political phenomena. This study uses documentation as the main data which is supported by interviews. The result of this research is that Jason Ranti has contributed in spreading critical insights to the younger generation. By understanding the meaning of eccentric musicalization through critical hermeneutic theory, Jason Ranti describes the current social phenomenon and tries to provide alternative responses for his listeners. The younger generation becomes more caring, empathetic and interested about the socio-political phenomena that are happening. Through Jason Ranti's critical music, the younger generation can take responsive actions in responding to the socio-political phenomena that are currently happening.
\end{abstract}

Keywords: Critical music, socio-political conditions, Jason Ranti, younger generation.

\section{PENDAHULUAN}

Musik kritis telah menjadi fenomena terutama pada kalangan muda, karena musik kritis membawa cara baru dalam mengkritisi kondisi sosial politik. Studi ini berfokus pada peran musik kritis dalam membangun kesadaran kritis terhadap masyarakat generasi muda. Umumnya musik kritis dibentuk karena adanya fenomena sosial yang terjadi, dan ditulis secara puitis sehingga menjadi lirik lagu. Salah satu musisi yang akan dibahas pada penelitian ini adalah Jason Ranti yang terkenal dengan musik folk-nya dengan musikalisasi yang nyeleneh. Jason Ranti atau lebih kerap dipanggil Jeje adalah seorang musisi Indonesia yang terkenal karena albumnya yang berjudul "Akibat Pergaulan Blues".

Musik ciptaan Jason Ranti dipilih karena musik-musik karya terkenal dengan kekuatan lirik lagunya yang kaya makna dan senantiasa menuangkan kepeduliannya terhadap kondisi sosial politik Indonesia lewat musik ciptaannya. Jason Ranti kerap menggambarkan realitas sosial kehidupan lewat kritisasi dan keresahannya terhadap kondisi sosial, politik, atau kebiasaan-kebiasaan anak muda, di mana mayoritas dari musik ciptaan Jason Ranti terinspirasi dari fenomena sosial politik yang sedang terjadi. Pemikiran-pemikiran Jason Ranti tersebut dituangkan lewat musiknya dengan lirik yang nyeleneh, blak-blakan, dan lugas. Lantas pemilihan diksi, makna eksplisit, dan sarkasme yang 
dituangkan Jason Ranti menjadi pembeda antara musisi indie lainnya. Pemilihan gaya bahasa itu pula yang mendekatkan musik kritis Jason Ranti dengan generasi muda. Sebagai seorang musisi, Jason Ranti senantiasa membangun komunikasi dengan para pendengarnya secara santai, hangat, namun juga berbeda dengan musisi lainnya. Dibalik sosoknya yang nyeleneh, Jason Ranti memiliki idealisme yang berbeda dibandingkan musisi lainnya.

Beberapa studi di dalam ilmu sosial melihat kontribusi musik dalam mendorong perubahan sosial. Menurut Abdullah Sumrahadi dalam tesisnya yang berjudul "Menemukan Kritik Sosial dan Kesadaran Kritis dari Musik Rock Indonesia" mengatakan bahwa kritik terhadap permasalahan sosial banyak dilontarkan sebagai bagian dari gerakan sosial dan ilmuwan dalam masyarakat. Dalam tesis ini Sumrahadi, meneliti model kritik yang dilakukan oleh para musisi dalam menanggapi permasalahan sosial melalui sentuhan kontemplasi dan artistik lewat musik yang mengandung kritik sosial. Tindakan dan aksi sosial diramu menjadi teks sosial atau kritik sosial lewat lirik lagu ciptaanya. Musisi kritis dalam karya seni nya dapat disandingkan sebagai “intelektual organik" yang dijelaskan oleh Gramsci (Gramsci, 1971). Menurut Sumrahadi, tindakan yang musisi lakukan lewat musik kritis mereka merupakan bentuk gerakan perlawanan terhadap keberadaan negara yang eksploitatif.

Pada studi ini, peneliti melihat manfaat musik kritis dalam mempengaruhi kesadaran generasi muda terhadap kondisi sosial politik bukan pada genre musik itu sendiri. Pada tesis Sumrahadi, beliau terfokus pada perkembangan musik rock dalam membentuk kesadaran kritis. Studi ini berusaha melanjutkan apa yang dilakukan oleh Sumrahadi itu, yakni tentang bagaimana lirik dalam musik kritis tersebut dapat menggambarkan kondisi sosial politik yang terjadi di Indonesia. Jason Ranti dipilih sebagai subjek penelitian karena musiknya yang terkenal kritis dan peka terhadap fenomena sosial politik yang terjadi di Indonesia. Selain itu, lewat idealisme dan ideologi yang dimiliki Jason Ranti menjadikannya sebagai sosok musisi yang inspiratif.

Sementara itu, Puji Laksono dalam tulisannya 'SUBKULTUR GRUNGE (Analisis Kritis Tentang Konstruksi Realitas Sosial dan Kesadaran Kritis musisi Grunge di Kota Surabaya)' menemukan bahwa melalui musik grunge, musisi grunge memiliki peran strategis sebagai revolusioner yang dapat membuka kesadaran kritis terhadap masyarakat umum. Kesadaran kritis ini meliputi legitimasi ideologis yang termasuk pada kondisi sosial politik negara (Laksono et al, 2015:28-29). Terdapatnya fenomena musik kritis terutama pada kalangan muda dalam membangun kesadaran sosial politik membuat Peneliti tertarik untuk melihat peran musik kritis ciptaan Jason Ranti. Pada penelitian ini, musik kritis Jason Ranti adalah musik-musik ciptaannya yang memiliki unsur kritis terhadap fenomena kondisi sosial politik negara. Apabila terdapat beberapa musik Jason Ranti yang tidak memiliki hubungan tentang kondisi sosial politik negara, maka tidak akan menjadi objek penelitian.

\section{KERANGKA TEORI}

Hermeneutika merupakan bagian dari ilmu sosial dan kemanusiaan. Dalam pemanfaatan teori hermeneutika, pemahaman tentang makna yang terdapat dalam sebuah teks merupakan objek dalam 
kajian nya. Berdasarkan etimologis, hermeneutika berasal dari bahasa Yunani yaitu hermeneuein yang berarti 'menafsir' dan hermeneia yang secara harfiah berarti interpretasi atau 'penafsiran'. Palmer membagi teori hermeneutika kedalam enam bentuk yang berbeda, yaitu: (1) Teori eksigesis Bibel (penafsiran kitab), (2) Metodologi filologi secara umum, (3) Ilmu pemahaman linguistik, (4) Pondasi metodologis geisteswissenschaften (ilmu kemanusiaan), (5) Fenomenologis keberadaan dan pemahaman eksistensial, (6) Sistem interpretasi (meliputi rekolektid dan ikonoklastis) (Palmer, 2003). Masing-masing dari bentuk hermeneutika tersebut diurutkan secara historis, namun, pada intinya tahapan tersebut menggambarkan peristiwa yang penting dalam masalah interpretasi. Karena dalam penelitian yang membahas karya sastra segala aktivitasnya berkaitan dengan interpretasi. Salah satunya dalam mempelajari makna dari musik kritik sosial karena karya musik tersebut perlu dimaknai dan diinterpretasikan. Sehingga dalam memahami makna dalam karya musik tidak terlepas dari hermeneutika.

Hermeneutika diartikan sebagai manusia yang sebenarnya (autentik) dapat dilihat berdasarkan konteks ruang (lokus) dan waktu (tempos) sehingga manusia dapat memahami desain (manusia otentik) yang tidak lepas dari konteks yang ada. Konteks yang hadir adalah sesuatu yang nyata dan apabila dihiraukan maka akan menjadikan manusia yang semu dan artifisial. Teori hermeneutika lahir dari metologi Yunani yaitu peran Dewa Hermes sebagai pembawa pesan dari Sang Mahadewa (orakel) yang berada di gunung Olympus kedalam bahasa yang dapat dimengerti manusia. Hermes lalu ditransmisikan kepada apa yang ada dibalik pemahaman manusia kedalam bentuk yang dapat ditangkap level intelegensi manusia (Eagleton, 1983). Apabila merujuk terhadap peran Hermes maka hermeneutika dapat dijelaskan sebagai ilmu dan seni dalam menginterpretasikan teks.

Todorov (1985) menjelaskan tujuan dari hermeneutika dalam mengungkapkan makna sebuah teks yang diteliti membutuhkan keadaan yang ideal. Agar teks itu dapat berbicara sendiri, dan keadaan yang tragis adalah ketika tidak dapat menemukan makna yang tunggal. Namun makna yang terikat pada pergeseran sejarah dan psikologis. Hal ini bertujuan agar pesan bisa dipahami lewat tiga bentuk makna dasar, atau hermeneuum dan hermeneia dalam pemanfaatan aslinya. Ketika persoalan yang berbeda ini pada akhirnya akan bermuara pada pemahaman. Paul Ricoeur adalah seorang filsuf Perancis, juga berpengaruh terhadap perkembangan studi hermeneutika pada era kontemporer (Bartens, 2001). Tidak hanya pada ilmu filsafat, Ricoeur juga menyumbangkan ilmunya pada pemikiran bidang sosial, politik, kultural, edukatif, dan teologis.

Teori hermeneutika yang dijelaskan oleh Ricoeur merupakan lanjutan dari proyeksi Schleiermacher tentang bahasa. Makna yang ditemukan dalam wacana ditulis dengan teks yang memiliki kenyataan luar biasa. Tidak ada manusia yang tidak melakukan pemaknaan dan penafsiran ketika seseorang sedang membaca teks. Interpretasi menjadi hal yang penting karena akan terjadi makna yang multilapis. Oleh karena itu pada dasarnya filsafat adalah hermeneutika dimana terjadi makna tersembunyi dalam teks yang terlihat memiliki makna. Interpretasi merupakan kegiatan dalam upaya membongkar makna-makna yang tersirat (Sumaryono, 1995). 
Ricoeur menjelaskan bahwa dalam memahami hermeneutik tidak terlepas dari pemikiran mengenai simbol, karena menurut Ricoeur simbol dapat membangkitkan pemikiran. Simbol dapat memberikan makna, sehingga makna yang diberikan tersebut tetap harus kembali dipikirkan. Tak semua bisa menjadi simbol, Ricoeur menjelaskan bahwa simbol berasal dari sebuah kesaksian yang berada pada ranah pengalaman. Ricoeur menjelaskan proses pemahaman yang menyebabkan perubahan dalam kehidupan manusia kedalam tiga tahap, yaitu, Pertama pada tahap ini terjadi pemahaman yang menghubungkan simbol dengan dunia, namun masih bersifat panoramik dan horizontal. Kedua, Manusia mulai masuk ke ranah hermeneutik yang menawarkan lingkaran hermeneutik (memahami makna-makna kegiatan sosial). Tahap terakhir adalah pemahaman simbol (tahap filosofis) dengan menilai peristiwa sosial berdasarkan fenomena yang terjadi (Ricoeur, 1974).

\section{METODE PENELITIAN}

Studi ini berfokus pada musik Jason Ranti yang terdapat dalam dua albumnya yang berjudul “Akibat Pergaulan Blues” (2017) dan Sekilas Info (2019) dan pengaruhnya dalam membentuk kesadaran kritis terhadap masyarakat masyarakat generasi kekinian. Seberapa jauh peran sebuah musik kritis dapat mempengaruhi empati masyarakat agar terbentuk kesadaran kritis terhadap kondisi sosial politik pada negara Indonesia. Karena diluar adanya berita lewat media massa atau online, kritisasi sebuah permasalahan sosial lewat sebuah musik dapat menjadi cara baru untuk membentuk kesadaran kritis.

Jason Ranti juga dikenal sebagai musisi yang nyentrik dan to the point. Dalam hal ini, musik ciptaan Jason Ranti baik yang terdapat didalam kedua album tersebut, atau merupakan single - single musiknya hanya terfokus pada musik kritik. Maka apabila terdapat beberapa musik Jason Ranti yang tidak memiliki makna sebagai kritik sosial tidak akan menjadi objek penelitian. Salah satu contohnya lagu yang berjudul "Variasi Pink" yang lebih mengarah kepada lagu romansa dan balada.

Metode Penelitian yang akan digunakan dalam penelitian ini adalah metode kualitatif dengan pendekatan fenomenologi. Moleong (2012) menjelaskan bahwa metode penelitian kualitatif merupakan penelitian yang bertujuan untuk memahami fenomena yang dialami oleh subjek penelitian secara deskriptif dan holistik. Dalam penelitian kualitatif melihat bawa realitas memiliki dinamika disetiap kejadiannya. Dengan menggunakan pendekatan fenomenologi, diharapkan Peneliti dapat memahami makna dari suatu peristiwa yang terjadi di lingkungan sosial manusia dan kemudian menjelaskannya pengaruhnya terhadap manusia lewat perilaku, motivasi, persepsi, dan tindakan lain yang dijelaskan secara deskriptif dan terstruktur.

Lewat penelitian kualitatif dengan pendekatan fenomenologi diharapkan Peneliti dapat menjelaskan makna dan situasi yang dialami subjek penelitian lewat karya musik kritis nya. Peneliti dapat menggali informasi berdasarkan pengalaman, perspektif, dan makna-makna di balik musik ciptaan Jason Ranti. Kemudian Peneliti dapat menginterpretasikan data yang didapat dengan pendekatan fenomenologi. 
Subjek penelitian ini adalah Jason Ranti. Subjektivitas Jason Ranti meliputi musik kritis ciptaannya yang terdapat dalam album "Akibat Pergaulan Blues" dan "Sekilas Info" dan pengaruhnya bagi kesadaran kritis generasi muda. Data dapat diperoleh lewat berita, wawancara online, podcast, jurnal ilmiah dan penelitian terdahulu tentang musik ciptaan Jason Ranti bersifat kritik sosial. Berita yang akan yang akan digunakan adalah berita-berita yang berhubungan dengan kritik sosial politik yang diungkapkan oleh Jason Ranti. Juga terhadap makna implisit yang terdapat dalam musik kritis ciptaanya. Lewat berita, jurnal ilmiah, dan penelitian terdahulu diharapkan dapat menggambarkan dan menceritakan fenomena sosial politik yang diciptakan Jason Ranti lewat musiknya.

Generasi muda yang termasuk dalam subjek penelitian adalah generasi muda yang mendengar, menyukai, atau mengikuti perjalanan karir dan musik-musik ciptaan Jason Ranti. Tidak menutupi kemungkinan bagi para anak muda yang baru mendengar musik Jason Ranti.Dengan hal itu Peneliti dapat melihat fenomena sosial yang terjadi dan dampak dari musik kritis karya Jason Ranti terhadap generasi muda. Sehingga Peneliti dapat menggambarkan ekosistem pemerintahan yang sedang berlangsung dan dampaknya terhadap generasi muda.

Dalam penelitian kuantitatif keterlibatan Peneliti dalam sebuah penelitian menjadi sangat penting sebagai instrumen utama. Peneliti bertugas sebagai interviewer dan observer. Penelitian ini berfokus pada musik kritis ciptaan Jason Ranti yang berhubungan dengan kondisi sosial politik maupun konstitusi Indonesia. Sehingga Peneliti memiliki tugas mulai dari perencanaan, pelaksanaan, pengamatan, dan pengumpulan data. Margono (2000) menjelaskan bahwa tugas Peneliti adalah untuk memberi pertanyaan seputar topik penelitian dan sebagai pengamat dalam proses penelitian. Sedangkan observasi adalah instrumen pendukung lain dalam sebuah penelitian.

Peneliti juga bertugas untuk menentukan informan yang berkompeten dalam menjawab pertanyaan penelitian yang terdapat pada rumusan masalah. Informan berdomisili di Jakarta, merupakan bagian dari penggemar musik kritis Jason Ranti dan bersedia memberikan data yang Peneliti butuhkan. Peneliti melakukan wawancara dengan Samuel Yohenson Yoce Matthews, S.H. karena ia tergabung dalam komunitas Gerombolan Woyoo dan Ahmad Ihsan Himawan yang merupakan seorang musisi solois indie dan juga seorang penyair puisi. Keduanya merupakan penggemar Jason Ranti dan telah mengikuti perkembangan musik kritis Jason Ranti sejak awal.

\section{HASIL DAN PEMBAHASAN}

Selama berkarier sebagai seorang solois indie, Jason Ranti berhasil membentuk dua album. Yaitu, Akibat Pergaulan Blues (2017) dan Sekilas Info (2019). Sebagai musisi, Jason Ranti tidak terlalu memfokuskan karyanya lewat level musikalitas yang tinggi atau aransemen yang kompleks. Karena Jason Ranti memiliki karakter yang kuat menjadi ruh atau nyawa dari setiap musik yang ia bawakan. Salah satu fenomena sosial yang berusaha diceritakan dalam musik kritis karya Jason Ranti adalah "Bahaya Komunis". Dimana fenomena ini berhasil menginspirasi Jason Ranti sehingga akhirnya ia 
menulis lagu tentang isu kebangkitan komunisme di Indonesia. Lagu ini dibalut dalam lirik yang sarkastik dan satire namun tetap memperhatikan makna dalam lirik lagunya.

Jason Ranti menjelaskan bahwa lagu Bahaya Komunis diciptakan bukan untuk mengedukasi masyarakat perihal isu kebangkitan komunisme, melainkan sebagai pilihan alternatif dalam menyikapi isu tersebut. Pada lagu ini, Jason Ranti menggunakan bahasa dan diksi yang hiperbola. Jason Ranti menjelaskan bahwa melawan hal-hal yang berlebihan memang harus menggunakan hal yang berlebihan. Menurut Jason Ranti, keresahan yang berlebihan oleh masyarakat Indonesia berpotensi mengancam keutuhan NKRI. Diharapkan dengan adanya lagu Bahaya Komunis dapat membuka alternatif dalam menanggapi isu komunisme di Indonesia. Jason Ranti menjelaskan bahwa situasi ini dapat berdampak buruk terhadap kesatuan dan integrasi masyarakat Indonesia.

Jason Ranti memiliki komunitas penggemar musik nya yang bernama "Gerombolan Woyoo". Dalam pemilihan nama komunitas, terinspirasi dari nama anak Jason Ranti yaitu Koko Woyoo Ranti. Komunitas Gerombolan Woyo tersebar di seluruh Indonesia, dan memiliki pusat dengan nama komunitas "Gerombolan Woyoo Pusat" dan memiliki satu kesamaan yaitu, lambang komunitas yang senantiasa menggunakan logo Jason Ranti.Komunitas Gerombolan Woyoo sangat beragam, dari segi ras, usia, asal daerah, kelas ekonomi, dan jenis kelamin. Lewat komunitas Generasi Woyoo, Jason Ranti dan karya-karya yang diciptakan dapat hidup dan berkembang hingga saat ini.

Hal ini menjadi bentuk segmentasi pasar musik kritis Jason Ranti, karena tidak semua kalangan menyukai musik folk maupun lirik-lirik nyeleneh yang disajikan oleh Jason Ranti. Walaupun komunitas ini terbentuk karena musik yang diciptakan Jason Ranti, kegiatan yang berlangsung dalam komunitas ini pun beragam dari pemutaran film buatan sesama Gerombolan Woyoo hingga futsal bersama. Kegiatan yang berlangsung dalam komunitas ini pun beragam, dari berita kehidupan Jason Ranti, informasi konser, penggalangan dana bencana alam, sampai ikut membuat toko yang menjual CD dan merchandise Jason Ranti yang bernama "Lapak Woyoo".

Generasi muda Indonesia termasuk dalam generasi $\mathrm{Z}$ dan generasi $\mathrm{Y}$ (Millennial) yang tumbuh dalam kondisi negara yang sedang berkembang terutama pada bidang teknologi informasi dan komunikasi. Secara harfiah belum ada yang bisa mengidentifikasikan generasi millennial secara demografi, namun para pakar sering kali menggolongkan berdasarkan tahun awal dan tahun akhir. Strauss dan Howe menjelaskan bahwa setiap generasi akan memiliki karakteristik umum yang nantinya menjadi karakteristik khusus dari generasi tersebut. Sehingga generasi millennial sangat terbiasa dengan perkembangan IPTEK, terutama pada teknologi komunikasi instan dan media sosial lainnya. Karena generasi millennial terlatih untuk mahir dalam teknologi dan infrastruktur maka hal ini berpotensi membawa generasi millennial jauh ke depan.

Pada masa pra-kemerdekaan Indonesia, generasi muda memiliki peran strategis dalam mempersatukan kekuatan NKRI dan mengambil alih kemerdekaan dari penjajah. Musuh generasi muda yang dulunya merupakan penjajah yang memiliki senjata menjadi ketidaktahuan dan ketidakmampuan dalam mengimbangi arus globalisasi yang begitu cepat. Presiden Jokowi menyebut tindakan ini sebagai 
"hijrah.” Upaya yang dapat dilakukan oleh generasi millennial adalah dengan mengubah kegaduhan menjadi kesatuan, pesimisme menjadi optimisme, dan ujaran kebencian menjadi ujaran kebenaran.

Maka dalam kondisi yang begitu dinamis, generasi muda harus tetap waspada dan senantiasa melihat kemajuan teknologi dari dua sisi. Keuntungan-keuntungannya dapat dimanfaatkan secara bijaksana dan maksimal, sehingga generasi muda tidak mudah larut dalam dampak negatif yang timbul dari kemajuan teknologi itu sendiri. Maka nalar kritis diharapkan dapat menjadi tumpuan yang kokoh agar generasi muda dapat terus konsisten berkembang kearah kemajuan. Dengan modal nilai luhur dan norma bangsa diharapkan dapat membentengi generasi muda dari ancaman radikalisme dan ekstrimisme yang bertebaran di internet. Dari awal perkembangan generasi muda, diyakini bahwa mereka adalah generasi yang mengedepankan nilai kritis dan nilai luhur.

Di Setiap konser dan pertunjukan live nya, Jason Ranti selalu membawakan musik nya dengan sederhana. Bermodalkan gitar, harmonika, dan lirik sindiran sumpah serapah, Jason Ranti dapat menyihir suasana konser menjadi hikmat. Dalam menulis lirik-lirik lagunya, Jason Ranti kerap terinspirasi dari kondisi sosial politik yang terjadi dalam kesehariannya. Pemilihan bahasa dan kemampuan penyampaian musik kritis yang dimiliki Jason Ranti ternyata menjadi daya tarik bagi para pendengarnya.

Keselarasan antara pemilihan bahasa dan aransemen musik ini lah yang menjadi nilai lebih yang dimiliki Jason Ranti di mata para generasi. Pemilihan bahasa yang digunakan oleh Jason Ranti dalam setiap musik kritis ciptaan nya memiliki pengaruh terhadap segmentasi pasar yang terbentuk. Dalam musik kritis yang diciptakan Jason Ranti menjadi sesuai dengan kriteria dan demand bagi kalangan generasi muda.

Segmentasi pasar musik kritis karya Jason Ranti identik dengan gaya bahasa keseharian generasi muda. Sehingga dalam penyampaian makna dari musik kritis tersebut lebih diterima oleh generasi muda. Tidak menutup kemungkinan musik kritis karya Jason Ranti juga dinikmati oleh masyarakat yang lebih tua, namun mayoritas dari penikmatnya merupakan bagian dari generasi muda. Terlihat dari kegiatan komunitas Gerombolan Woyoo yang kebanyakan bagian dari generasi muda. Jason Ranti pernah diundang dalam konser "Yang Muda Menolak Lupa" yang ternyata dalam konser itu diselundupi kampanye paslon Pilpres 2019. Panitia konser ini melihat kemampuan Jason Ranti dalam mempengaruhi kecenderungan pemilih generasi muda.

Musik kritis karya Jason Ranti telah ikut berkontribusi sebagai komunikasi massa terhadap penyampaian kritik dalam membangun kesadaran kritis. Jason Ranti kerap menggunakan bahasa-bahasa yang nyeleneh dan unik, dimana pemilihan lirik tersebut yang menjadi daya tarik bagi generasi muda.

Studi ini menggunakan teori hermeneutika kritis oleh Habermas yang menerapkan bentuk terobosan baru dalam menjembatani ketegangan antara objektivitas dengan subjektifitas, antara teori dengan praktis, dan antara idealitas dengan realita (Atabik, 2013:449). Bahwa dalam studi ini, Peneliti berusaha melihat subjektifitas dalam objektifitas musik kritis karya Jason Ranti. 
Salah satu musik kritis yang akan dibahas dalam penelitian ini adalah Bahaya Komunis yang terdapat dalam album Akibat Pergaulan Blues. Secara objektif, lirik musik tersebut menggambarkan tokoh yang merasa bahwa bahaya paham komunisme dapat ditemukan ditempat-tempat yang sebetulnya tidak memiliki hubungan dengan komunisme. Pada lagu ini, Jason Ranti menggunakan majas hiperbola yang digambarkan dengan lirik-lirik yang unik.

Meskipun demikian, apabila pemaknaan dilakukan lebih mendalam dengan memanfaatkan makna subjektif pada teori hermeneutika kritis, Jason Ranti mencoba menggambarkan respond hiperbola masyarakat Indonesia. Bahwa lewat musik Bahaya Komunis diharapkan masyarakat Indonesia tidak mentah menerima isu yang belum jelas sumbernya. Jason Ranti berusaha memberikan respon alternatif bagi masyarakat Indonesia. Bahwa dengan menggambarkan paranoia masyarakat Indonesia, diharapkan dapat membangun kesadaran kritis terhadap isu hoaks tersebut. Sebagaimana yang terjadi di Indonesia ketika fenomena isu masuknya komunisme tiba-tiba viral yang dapat menyebabkan disintegrasi bagi Indonesia.

\section{KESIMPULAN}

Jason Ranti sebagai seorang musisi yang dikenal dengan musik kritis terhadap kondisi sosial politik, telah memanfaatkan kemampuannya dalam menggambarkan fenomena sosial yang terjadi di Indonesia.

Pertama, Jason Ranti telah ikut berkontribusi membangun kesadaran terhadap kondisi sosial politik yang terjadi di Indonesia lewat musik kritisnya. Sehingga Jason Ranti kerap menggambarkan fenomena sosial yang terjadi di Indonesia dengan menggunakan bahasa yang terkesan ngasal namun bukan tanpa maksud, binal tapi estetis, dan menggelitik namun kritis. Lewat lirik musik nya, Jason Ranti kerap menggunakan makna sarkasme dan satire.

Pemilihan bahasa dan cara penyampaian musiknya lantas menjadi pembeda antara musik kritis Jason Ranti dengan musisi lainnya. Terutama bagi generasi muda, dimana karakteristik generasi muda cenderung lebih kritis, anti kemapanan, dan tidak peduli sistem. Lewat gaya bahasa yang nyeleneh tersebut Jason Ranti gunakan pada musik kritisnya, telah membangun rasa ingin tahu dan ketertarikan bagi generasi muda. Karena musik kritis karya Jason Ranti kerap menggunakan makna implisit dalam menggambarkan suatu fenomena sosial.

Kedua, generasi muda menjadi lebih peka dan peduli terhadap kondisi sosial politik lewat pengaruh musik kritis karya Jason Ranti. Berdasarkan hasil penelitian, generasi muda mulai mendengar musik kritis karya Jason Ranti karena liriknya yang menggelitik dan untuk asikasikan saja. Namun karena adanya lirik yang nyeleneh itu sendiri yang membangun curiosity kepada generasi muda. Sehingga generasi muda menjadi lebih tertarik untuk mencari tahu tentang fenomena yang melatarbelakangi musik kritis ciptaan Jason Ranti. Selain karena rasa ingin tahu, kesadaran kritis juga terbentuk karena generasi muda merasa relatable dengan musik kritis tersebut. 
Ketiga, terdapat peningkatan kesadaran terhadap kondisi sosial politik bagi para pendengar musik kritis karya Jason Ranti. Peningkatan kesadaran terlihat dari urgensi generasi muda untuk take action dari pengetahuan atau kesadaran kritis yang mereka dapatkan dari memaknai musik kritis karya Jason Ranti. Secara personal, generasi muda menjadi lebih peduli terhadap kondisi sosial politik yang terjadi dan buah dari kepedulian itu adalah mereka menjadi lebih berani untuk mengutarakan pendapat apabila pendapat itu benar. Apabila melihat peningkatan kesadaran kritis bagi generasi muda secara perkelompokan terlihat dari aktivitas Gerombolan Woyoo sebagai komunitas penggemar Jason Ranti.

Karakter tersebut lantas yang membentuk kharisma dan karakteristik Jason Ranti menjadi imajinatif dan inspiratif. Namun, tidak seluruh kalangan masyarakat bisa menerima musik yang membicarakan narkoba, pekerja seks komersial, maupun sumpah serapah yang sering Jason Ranti gunakan dalam lirik musiknya. Sehingga dari segi kuantitas pendengar musik kritis karya Jason Ranti belum bisa sampai mempengaruhi atau mengguncang status quo. Karena pemilihan bahasa yang bisa dibilang explicit, membentuk segmentasi pasar yang cukup spesifik. Dalam musik kritisnya, Jason Ranti juga cenderung berada di zona "abu-abu" yang merupakan zona yang paling aman. Karena lirik musik yang bisa dibilang kurang merakyat menyebabkan pasar pendengar Jason Ranti lebih "deep" dibandingkan lebih "wide".

\section{DAFTAR PUSTAKA}

Agung (2010) Abdullah Sumrahadi: Membangun Kesadaran Kritis Melalui Musik Rock. Accessed 22 Feruary 2021. from https://ugm.ac.id/id/newsPdf/2151-abdullahsumrahadi-membangunkesadaran-kritis-melalui-musik-rock.

Atabik A (2013) Memahami Konsep Hermeneutika Kritis Habermas. STAIN Kudus, 1(2), 449.

Bartens K (2001) Fllsafat Kontemporer - Perancis. Jakarta: Gramedia.

Eagleton T (1983) Literary Theory: An Introduction. London: Basil Blackwell.

Gramsci A (1971) Selection from the Prison Notebooks. New York: International Publisher.

Laksono P, Kartono DT, \& Demartoto A (2015) Subkultur Grunge (Analisis Kritis Tentang Konstruksi Realitas Sosial dan Kesadaran Kritis Musisi Grunge di Kota Surabaya. Jurnal Analisa Sosiologi, $4(1)$.

Margono (2000) Metodologi Penelitian Pendidikan. Jakarta: Rineka Cipta.

Moleong LJ (2012) Metode Penelitian Kualitatif. Bandung: PT. Remaja Rosdakarya.

Palmer ER (2003) Hermeneutika Teori Baru Mengenal Interpretasi. Yogyakarta: Pustaka Pelajar.

Ricoeur P (1974) Existence and Hermeneutics in The Conflict of Interpretation: Essay in Hermeneutics, ed. Don Ihde. Evanton: Northwestern University Press.

Sumaryono E (1995) Hermeneutik: Sebuah Metode Filsafat. Yogyakarta: Kanisius.

Todorov T (1985) Tata Sastra. Jakarta: Penerbit Jembatan. 